\title{
Dramaturgia de avaliação: o teatro político dos anos $1970^{1}$
} REINALDO CARDENUTO

\begin{abstract}
"Quando for preciso fechar o livro, farei isso sem nada lamentar. Vi tanta gente viver tão mal, e tanta gente morrer tão bem.”

[Citação de Jean-Luc Godard a um poema de Luis Aragon no filme Je vous salue Sarajevo (1993)]
\end{abstract}

\section{O nacional-popular}

$\mathrm{P}$ OR MOTIVOS diversos, em especial o cenário político autoritário e repressivo do Brasil pós-1968, os dramaturgos de formação marxista, vindos do Teatro de Arena, do Centro Popular de Cultura e do Grupo Opinião, adentraram a década de 1970 com uma sensação de vazio. No embate contra a censura governamental às artes, vivendo uma forte crise econômica no mercado teatral e a indisposição crescente do meio artístico em relação ao viés ideológico comunista, autores de esquerda, que nos anos anteriores haviam estabelecido o compromisso de representação política da classe popular, passavam pelo mal- estar da derrota, da apreensão diante de um país cuja modernização se dava ao avesso do que compreendiam como projeto de mundo. Dos destroços de uma dramaturgia com traços românticos e que apostara na crítica ao capitalismo a partir de um povo idealizado em herói, em vanguarda combatente de nosso subdesenvolvimento, saíam vencidos, no campo ideológico, Gianfrancesco Guarnieri, Oduvaldo Vianna Filho, Augusto Boal, Paulo Pontes, João das Neves e outros. A seu modo, cada um articulava-se para responder a duas inquietações centrais vividas no período: de um lado, os palcos cada vez mais esvaziados de uma concepção marxista de arte; de outro, os meios de comunicação de massa, especialmente a televisão, preenchendo a ausência de um popular símbolo de luta política por outro mais palatável para o desenvolvimento de uma indústria cultural.

Mesmo diante desse cenário de colapso da dramaturgia em afinidade à perspectiva comunista, em que foram recorrentes censuras às encenações de peças da esquerda, os autores aqui citados procuraram, no decorrer da primeira metade dos anos 1970, rearticular uma proximidade da escrita ficcional com o popular politizado. A expectativa de não interromper o compromisso ideológico com essa classe passava pela leitura de que a compreensão profunda das contradições sociais do Brasil partia necessariamente da representação do povo. Embora o projeto anterior de revolução socialista, com excessos de ingenui- 
dade, tenha entrado em falência com a ascensão dos militares ao poder, esses dramaturgos não descartaram a manutenção de um teatro político capaz de se tornar espaço fundamental para o debate público em torno das crises enfrentadas por um país que adentrava aos atropelos no capitalismo avançado. $\mathrm{O}$ recuo histórico da esquerda tradicional, cuja origem esteve em grande parte ligada ao $\mathrm{PCB}$, não deveria levar à paralisia do marxismo artístico à brasileira ou à adoção da tradição teatral encabeçada por José Celso Martinez Corrêa, de rompimento estrutural com a criação realista de base materialista histórica. Mesmo que a avaliação recente tivesse, por meio de filmes como Terra em transe (1967), de Glauber Rocha, demonstrado os erros da esquerda, em especial a ilusão de que havia no Brasil da década de 1960 uma vanguarda prestes a tomar o poder, cabia à arte politizada oferecer um foco de resistência à chamada "modernização conservadora" e realizar uma revisão da dramaturgia anterior com a finalidade de conservar, no teatro, uma prática pulsante de reflexão crítica sobre o país.

Diante de certa flexibilização da censura em meados dos anos 1970, motivada em parte pela gradual abertura política iniciada no governo Ernesto Geisel, ganhou força esse projeto de retomar e revisar uma dramaturgia inserida na tradição combativa do nacional-popular. Em anos passados, especialmente antes do AI-5, de 1968, boa parte da dramaturgia influenciada pelo comunismo havia, como ideário de militância, confiado na certeza de que a solução para as contradições do Brasil, em especial para o seu subdesenvolvimento, estaria na formação de uma vanguarda esclarecida na qual o povo, motor revolucionário, seria orientado pela intelectualidade marxista. Realista por definição, seja em um realismo de fundo lukácsiano, de inspiração no proletkult ou brechtiano, a ficcionalidade da esquerda, em sua multiplicidade temática, aparecia nos palcos impregnada por uma leitura esquemática de mundo, com boa dose de teleologia, na qual reverberava a crença de que era possível tomar posse da história e conduzi-la, não sem sacrifícios, em direção ao socialismo. Os dramaturgos de formação marxista, dos mais adeptos aos manuais comunistas, como Vianinha, aos menos crédulos em relação ao programa do PCB, caso de Augusto Boal, escreveram peças que espelharam, em graus diversos, a confiança histórica no papel da esquerda como reformuladora do mundo. Em textos como Eles não usam black-tie (1958), Gimba, presidente dos valentes (1959), Brasil, versão brasileira (1962), Opinião (1964), Arena conta Zumbi (1965) e Arena conta Tiradentes (1967) a constante está em um popular que mesmo sofrendo derrotas na ficção carrega em si traços de um heroísmo exemplar, além da essência de uma cultura considerada pela esquerda como originalmente brasileira.

Embora essas peças tenham contribuído intensamente para a atualização do teatro em relação aos debates estéticos do modernismo, tornando-se marcos de afirmação da autoria nacional e operando o rompimento com a nossa tradição do drama burguês, a dramaturgia marxista dos anos 1950 e 1960 gerou um idealismo que acabou por afastar a criação teatral realista de uma análise mais complexa da sociedade brasileira e de suas fissuras. Tendo por "estrutura de sen- 
timento" 2 uma leitura comunista de mundo, arriscando nas encenações das peças formas que permitissem convocar o espectador a ler o Brasil a partir da luta de classes e do avanço inevitável do marxismo, os autores acabaram por preterir as profundas contradições existentes no interior da camada popular e passaram a articular um conceito político de povo, um símbolo de vanguarda em luta que se conformava mais a seus anseios de engajamento do que a uma representação crítica da existência social desta classe. O povo dos palcos - grevistas, malandros e agentes de transformação histórica -, mesmo construído a partir da pesquisa na realidade, se configurou em síntese de um desejo revolucionário que não se transformou em práxis na década de 1960. A ficção teatral da esquerda, em sua negociação com o real, aprisionou o popular no "realismo" de sua própria militância monolítica e apostou no elogio a uma vanguarda capaz de projetar a nação em uma modernidade avessa ao capitalismo. Não à toa, depoimentos dos autores, no decorrer de suas vidas, recorrentemente retomaram o assombro vivido por alguns no imediato pós-golpe de 1964: heroicizado na dramaturgia, o povo assistiu passivo a emergência dos militares ao poder. Com o avançar dos anos, com o endurecimento gradual da ditadura, tornava-se evidente a fissura entre a síntese do Brasil projetado nos palcos e o país comandado por generais.

O mal-estar gerado pela fissura observada nesse teatro idealista, que levou posteriormente os dramaturgos marxistas a acusarem sua própria visão equivocada de historicidade e a adotarem o conceito de populismo para explicar a heroicização do povo, não implicou, no entanto, um desligamento do compromisso de suas peças em relação ao nacional-popular. Quando do referido abrandamento da censura, em meados dos anos 1970, com a oportunidade de recolocar o teatro militante como análise crítica de Brasil, os autores decidiram resgatar a tradição por eles iniciada tomando o cuidado de revisá-la em profundidade, evitando uma concepção mecanicista, ultrapassada pelos próprios acontecimentos históricos, a partir da qual as contradições da classe popular e da nação anulavam-se, ou mostravam-se passíveis de solução, na linearidade do desenvolvimento dramático. Se a escolha era não apagar a tradição de engajamento, era manter os eixos temáticos que estavam na origem da dramaturgia de viés comunista, reconvocando-os como possível caminho de reflexão, a solução passava pelo repensar da representação de povo e por redefinições no papel que as peças poderiam assumir em um contexto de crise política da esquerda.

Dos depoimentos concedidos e escritos redigidos pelos dramaturgos em torno da revisão do nacional-popular, possivelmente a apresentação da peça Gota d'água (1975), por Paulo Pontes e Chico Buarque, seja o que melhor sintetiza, à época, o novo projeto que a esquerda tradicional tentava consolidar no teatro. Em consonância com o Vianinha da entrevista a Ivo Cardoso (Vianna Filho, 1983, p.174-87), em 1974, e com o Guarnieri em conversa com Fernando Peixoto (1985, p.44-60), em 1978, os autores de Gota d'água iniciam o texto, praticamente um manifesto de intenções, com uma reflexão sobre como o regime militar utilizou a sua condição autoritária para implantar uma ordem ca- 
pitalista "radical, violentamente predatória, impiedosamente seletiva" (Buarque; Pontes, 1977, p.xi) a partir do qual se acelerou o empobrecimento do povo e a concentração de rendas enquanto os setores avançados da classe média, outrora responsáveis pela rebeldia na área cultural, passaram a ser cooptados pela indústria cultural. Partindo de uma leitura adorniana, eles acusavam a acomodação do inconformismo como consequência da modernização instalada sob a regência do "milagre econômico" e, mais fundamental, a situação cada vez mais miserável do popular: posta à margem nos programas do governo e sem representação ideológica nos processos artísticos industriais, "às classes subalternas restou a marginalidade abafada, contida, sem saída. [...] Como classe, estão reduzidas à indigência política" (ibidem, p.xv).

O popular, que fora, mesmo idealizado, o centro do que Paulo Pontes e Chico Buarque consideram no texto "uma das fases mais criativas da cultura brasileira" (ibidem, p.xvii), encontrava-se para eles, naquele momento, em um processo acelerado de apagamento histórico, à deriva em um país ditatorial que parecia conduzir o seu desenvolvimento econômico a partir da opressão em massa das classes subalternas. Distante daquela leitura do miserável que nos anos 1950 e 1960 se tornaria vanguarda revolucionária, a percepção da esquerda tradicional era de esgotamento, de um povo que parecia condenado, como sugerido por Ruy Guerra, em seu filme $A$ queda (1978), a esperar sua transformação em bois a serem industrialmente massacrados no matadouro da História. Diante da percepção desse colapso, da melancolia da derrota, a dramaturgia de viés marxista não encontraria disposição para reencenar pretensões revolucionárias e muito menos a condição de projetar novas idealizações de futuro. Se uma das principais conclusões da apresentação de Gota d'água estava na necessidade de manter o compromisso da dramaturgia de esquerda com o nacional-popular, de que era preciso "tentar, de todas as maneiras, a reaproximação com nossa única fonte de concretude, de substância e até de originalidade: o povo brasileiro" (Buarque; Pontes, 1977, p.xvii), isso significava também reconhecer que reconduzir as classes subalternas aos palcos implicava na desistência da positividade anterior em nome de outra dialética cuja força, em tempos ditatoriais, estaria em observar criticamente os sintomas de uma sociedade em crise.

Em vez de afundar na estagnação provocada pela perplexidade diante dos rumos da sociedade brasileira ou de adotar a linha de um teatro em fuga do real, Paulo Pontes e Chico Buarque procuravam, em seu quase manifesto, convocar o teatro político a reintroduzir o popular em cena como ponto de partida para expor os mecanismos de dominação que a ditadura buscava encobrir com a censura e nos meios de comunicação. A dramaturgia de engajamento, como forma de resistência, deveria operar uma resposta crítica aos excessos dos militares no poder, denunciando na medida do possível os abusos autoritários, crimes e torturas praticados em nome da "segurança nacional" e do desenvolvimento do país. Ao propor uma construção dramática sem o esquematismo ideológico anterior, o novo projeto tinha a pretensão de analisar em profundidade as violentas 
contradições vividas pelo Brasil dos anos 1970, retomando o compromisso do teatro com a conscientização do espectador. Nesse sentido, em direção oposta às peças que foram escritas para o Centro Popular de Cultura, nas quais se buscavam ocultar as fissuras políticas para preservar um programa de militância, tratava-se, como explicou Vianinha em 1974, de descobrir a tragédia, de "não fugir dela, não mascarar nada, ir ao máximo possível às condições de nossa fragilidade, descobrir até o fundo as nossas impotências, as nossas incapacidades" (Vianna Filho, 1983, p.183). Estava em jogo a criação de um contradiscurso que permitisse expor o negativo da propaganda oficial da ditadura.

Todo esse debate encontra-se na origem da peça Gota d'água. Adaptando Medeia, de Eurípedes, para o Brasil de meados da década de 1970, os autores atualizam o texto grego recolocando-o em um conjunto habitacional carioca onde Joana, abandonada pelo amante Jasão, comete suicídio após envenenar os filhos. Ao recontar o enredo da tragédia, utilizando-se de sua estrutura para comentar criticamente aspectos da situação nacional, Paulo Pontes e Chico Buarque reconduzem politicamente o popular aos palcos, criando personagens e cenas que permitam desvelar sofisticadas engrenagens de dominação existentes na modernização levada a cabo sob o governo militar. Como o caso de Jasão, compositor de sambas, que negocia com os poderosos a comercialização dos valores do povo e da própria vida; ou as artimanhas de Creonte, empresário, para esvaziar, com favores, as manifestações opostas às altas prestações que cobra pela venda de casas populares. Contando com uma elaborada construção dramática, com músicas e diálogos escritos em verso, Gota d'água é a denúncia de um Brasil conduzido pelos desígnios de uma elite voraz que suprime a voz política da esquerda: ao término do enredo, o coroamento de Jasão como genro e sucessor de Creonte, ao preço do suicídio de Joana, expõe o desencanto de observar a assimilação da possível rebeldia contida no popular. Sucesso de público, a peça abria, nos palcos, caminho para essa dramaturgia de engajamento que estava reavaliando o seu lugar e direcionando o olhar para a tragédia enfrentada por uma classe subalterna à margem da sociedade.

A possibilidade de retomar no teatro a discussão crítica da situação nacional, a partir dessa ficcionalidade de construção política menos idealizada do popular, ganhou força nos meses seguintes à encenação de Gota d'água, quando foram montadas Muro de arrimo (1975), de Carlos Queiroz Telles, e O último carro, de João das Neves. Enquanto a primeira peça era o monólogo de um pedreiro que projetava sobre a seleção brasileira de futebol a alegria não encontrada em sua vida cotidiana, a segunda, de inspiração em Brecht, gerava a alegoria de um Brasil em colapso a partir da imagem de um trem desgovernado que ao término da narrativa bate em um muro e provoca a morte da maioria de seus passageiros. Escrita originalmente em 1967, mas liberada pela censura para montagem apenas em 1976, a peça de João das Neves, leitura das angústias da esquerda, é dividida em dois atos. No primeiro, um painel de quadros sociais aparentemente sem ligação dramática introduz em cena crises enfrentadas por 
personagens do subúrbio carioca que viajam no trem: o casal de mendigos, ele egoísta e ela submissa, que tem o dinheiro surrupiado pelo guarda da estação; a prostituta que vende o corpo no último vagão e é obrigada a servir dois violentos malandros; o camponês que se engana com o preço da cocada e é destratado pelo vendedor ambulante; a menina Judith que brinca no chão com a urina de um bêbado; entre outros. Exceção a Beto, que promete casar com a namorada grávida, e aos operários cuja discussão se concentra na melhor forma de militar politicamente na fábrica, os personagens de $O$ último carro encontram-se destituídos de romantismo e revelam, em suas ações, um popular em decomposição, como se a miséria social passasse a corromper o próprio espírito das classes subalternas.

O segundo ato cujo início se dá com a descoberta de que o trem onde estão os personagens encontra-se desgovernado, gera um processo de reversão das expectativas do drama tradicional. Em vez de apresentar desfechos para os dilemas anunciados na primeira parte do texto, João das Neves os agrava a partir de uma estrutura em choque que intensifica o descontrole vivido pelo popular: enquanto os operários assumem a tarefa de tentar evitar o desastre, um beato, alegoria da alienação religiosa, consegue convencer parte dos passageiros a ficar no trem ao prometer a felicidade pela transcendência. Ao término da narrativa, apesar de alguns se salvarem, um dos operários, Deolindo, acaba por sacrificar-se. Pelo estranhamento da situação, o ato heroico, no entanto, acaba por soar inverossímil, repleto de incompletudes, como se o autor, já em 1967, anunciasse a impassibilidade de reconduzir ao palco aquele popular representação da vanguarda revolucionária. Não à toa, ao apresentar a peça em 1976, defendendo a sua atualidade no Brasil de meados dos anos 1970, João das Neves (1981, p.59) explica como $O$ último carro representa "um universo trágico, regido por deuses cegos de Olimpo sem grandeza, num mundo que não produz mais heróis porque o heroísmo está encravado na luta cotidiana pela sobrevivência de toda a população de uma cidade, de um país, de um mundo".

A morte simbólica do popular anteriormente idealizado, somada aos esforços de Gota d'água e de O último carro em reassumi-lo como ponto de partida para uma reflexão crítica sobre a situação nacional, levaria o filósofo marxista Carlos Nelson Coutinho (1981, p.61), em seu artigo "No caminho de uma dramaturgia nacional-popular”, publicado ainda em 1976, a concluir, a partir do exame das duas peças, como na dramaturgia militante à época

uma recepção menos "otimista” e mais complexa do conteúdo popular tornou-se a base de uma superação do abstrato populismo cepeano; e, em ligação com isso, a linguagem teatral - a forma dramática - assumiu uma espessura simbólica capaz de deixar de lado certa ingenuidade "didática" que marcara nossas anteriores experiências no terreno do "teatro político".

De fato, ao apostar na revisão de seu teatro, a esquerda ofereceu aos espectadores, pelo menos no campo das ideias, um importante refúgio crítico ao 
discurso desenvolvimentista sustentado pelos militares. Ao centrar-se no drama enfrentado pelas classes subalternas, para eles o lugar simbólico em que a tragédia brasileira se revelava mais perversa, possibilitaram o retorno a uma tradição crítica de teatro marxista que foi capaz de promover, mais abertamente, a denúncia da ditadura e das fissuras de uma sociedade em crise. Em sua dimensão política, no entanto, essa "dramaturgia de avaliação" não se restringiria apenas à revisão e ao resgate do nacional-popular como princípio de criação ficcional. Seus autores, a maioria formada nos quadros do PCB, ainda teriam que acertar contas com duas questões que muito os inquietavam: qual seria, afinal, o lugar reservado ao militante tradicional da esquerda no Brasil pós-1968 e, dentre as possíveis formas dramatúrgicas, qual permitiria, em tempos sombrios, uma aproximação crítica mais eficaz com os espectadores.

\section{A militância e a forma dramática}

No decorrer dos anos 1950 e 1960, na tradição idealista já comentada, o dramaturgo, como agente político de esquerda, pouco se autorrepresentou nos palcos. Nas raras peças em que o militante marxista, de lugar social distante do povo, transformou-se em figura do conflito dramático, a tendência foi o elogio ao combatente que, numa síntese entre culpa histórica e traição à sua classe de origem, sacrificava o conforto burguês em nome de um projeto revolucionário. Assim funcionava em A vez da recusa (1963), de Carlos Estevam Martins; em Opinião (1964), na qual a personagem de Nara Leão descobria a sua missão no engajamento; ou mesmo em Arena conta Tiradentes (1967), na qual, já em uma perspectiva de resistência à ditadura, Guarnieri e Boal analisam por parábola o golpe militar, assumem a tarefa de expor os mecanismos de poder da elite e enaltecem a mobilização política de Tiradentes ao sintetizar, sob a figura do coringa, o espírito crítico e provocador da militância de esquerda. Na maioria dos textos encenados à época, no entanto, o discurso de uma esquerda que não duvidava de seu papel como agente de transformação, confiante em uma ciência comunista de manual capaz de exercer soberania sobre a História, apresentava-se nas entrelinhas da ficção idealizada do universo popular. No povo romantizado como "classe para si", para utilizar uma expressão de Karl Marx, encontravam-se abrigados os traços de certa "arrogância" da esquerda tradicional, exposta em textos como $O$ anteprojeto do manifesto do CPC (1962), de Carlos Estevam Martins (1979, p.67-80), que define a condição do intelectual e artista marxista como detentor da verdade e condutor de uma massa politicamente alienada. Embora nem todos os dramaturgos compartilhassem dessa perspectiva, e uma peça como Revolução na América do Sul (1960), de Boal, já assumia dúvidas, fato é que mais uma vez a "estrutura de sentimento" comunista tornava difícil, ainda mais antes de 1964, escapar a um viés ideológico otimista.

A derrota provocada pela ascensão dos militares ao poder, agravada pelo aumento da repressão após 1968, geraria entre os dramaturgos marxistas a angústia de descobrir o colapso do projeto revolucionário e a própria ilusão de ter 
assumido a crença em uma teleologia fácil de fundo socialista. Entre companheiros de luta aprisionados, torturados, mortos e exilados, a sensação de vazio político, que surgia ao observar o povo posto à margem, também nascia da percepção de que o governo militar promovia o desmanche dos focos de atuação da esquerda. Diante desse quadro de frustrações, no qual a ordem é resistir de alguma forma, é buscar algum modo de enfrentamento, os autores passaram a intensificar a sua autorrepresentação dentro da ficcionalidade teatral. Estava em jogo, na avaliação do engajamento político, um processo fundamental de busca para esta geração. Com a consciência de que colocar no centro da criação dramática o militante desterrado significava, por extensão, gerar uma reflexão crítica sobre a situação nacional, diversas peças passaram a incluir na narrativa, de modo latente ou não, uma das grandes inquietações dos dramaturgos: afinal, se há um lugar possível de atuação da esquerda no Brasil dos anos 1970, qual seria esse? E se a crença revolucionária anterior mostrava-se impossível no novo contexto histórico, que base política permitiria resgatar uma tradição de luta?

Nessa "dramaturgia de avaliação", uma das leituras em torno do militante, ainda sob a asfixia provocada pela presidência de Emílio Garrastazu Médici, é a da esquerda em profunda agonia, qual um moribundo a temer que o último suspiro o conduza ao desaparecimento histórico definitivo. Sem vislumbrar saídas, estarrecido diante dos acontecimentos, o teatro político fez de suas próprias impossibilidades o centro da criação e curiosamente definiu sua aporia, seu estado de quase morte, como ponto de partida para manter a postura crítica em torno da situação nacional. Assim, em Check-up (1972), partindo do uso da metáfora talvez para escapar da censura, Paulo Pontes cria uma situação que beira o fantástico kafkaniano ao internar Zambor, velho ator com problemas de úlcera, em um hospital regido por burocracias sem sentido no qual o artista tem seu corpo submetido às decisões das autoridades. Nesse hospital, evidente representação do Brasil ditatorial, o protagonista encontra-se encurralado, sob os cuidados de um médico e de uma freira que procuram, a partir de um tratamento sem fim, anestesiar seu espírito rebelde. Embora tente fazer do deboche uma arma contra seu aprisionamento, com o tempo Zambor vê o mal-estar intensificar-se, ainda mais após a entrada em cena de Jair, jogador de futebol que representa um popular passivo a aceitar o controle imposto pelos médicos em troca de conforto e estabilidade. Em constante fricção com os mecanismos repressores, o protagonista acaba por morrer justamente quando, após fingir ter formação em medicina, consegue estabelecer um diálogo com as autoridades que passam a respeitá-lo. Paulo Pontes parecia estar disposto - essa é uma possível leitura da peça - a sugerir o falecimento simbólico do militante, aqui travestido em ator, quando de sua disposição em negociar, mesmo na base da malandragem, com os donos do poder. Em Check-up, diante da pergunta "que fazer?", a conclusão é melancólica, sem saída: mesmo com os esforços em reorganizar o engajamento político como resistência, parecia inevitável a contenção da rebeldia e o esmagamento da esquerda. 

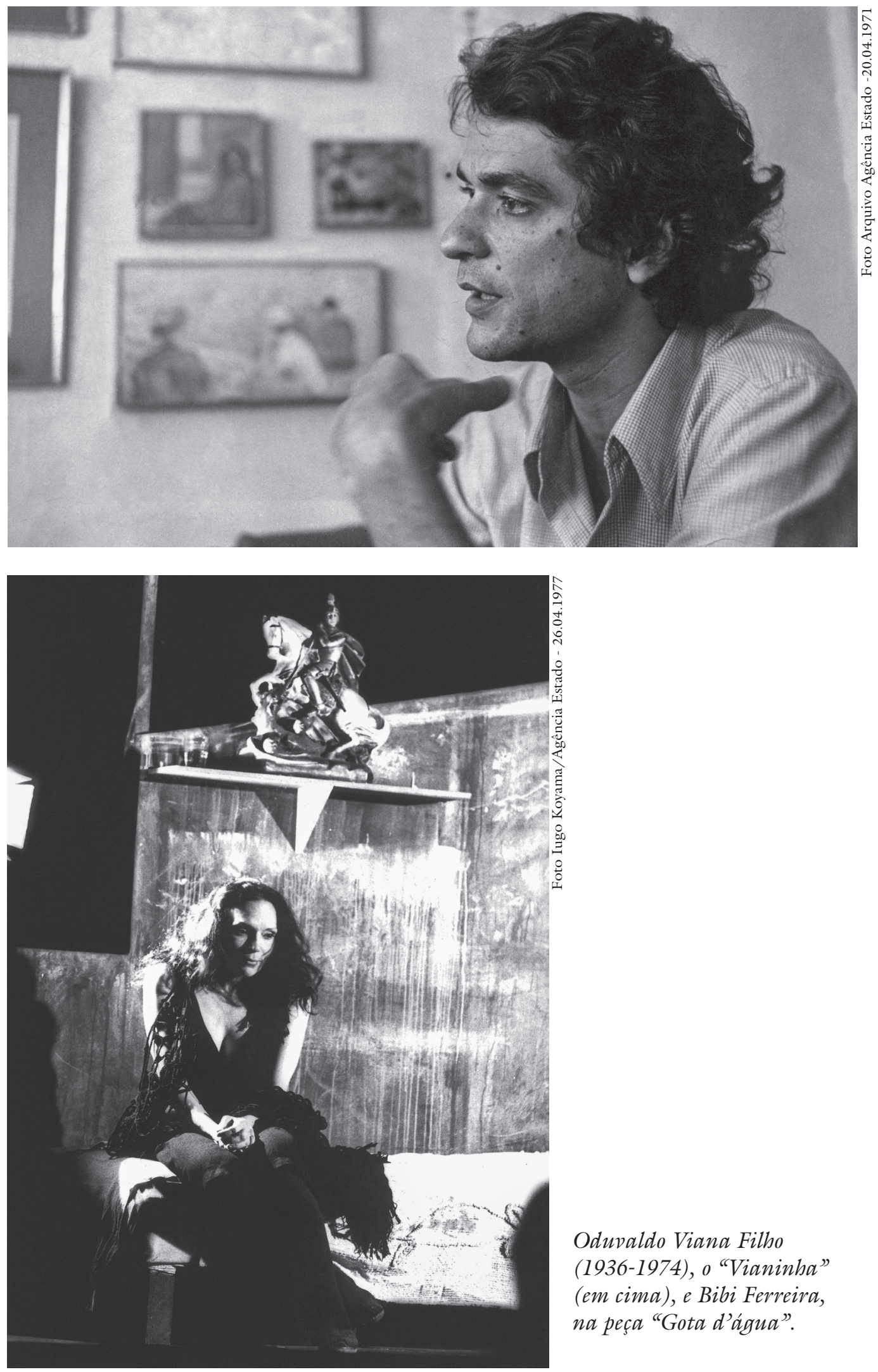

Oduvaldo Viana Filho (1936-1974), o "Vianinha" (em cima), e Bibi Ferreira, na peça "Gota d’água”. 
Narrativas cujo centro dramático foi elaborado a partir de situações opressivas, de difícil escape, como a representar o cerco organizado pela ditadura em torno do engajamento, foram comuns nos anos 1970. Enquanto Vianinha, sem citar diretamente a condição do militante de esquerda, criava na televisão, na emissora Globo, textos como Noites brancas (1973), adaptação do romance de Dostoiévski, e Turma, doce turma (1974), ambos a tratar da impossibilidade de fuga diante da "modernização conservadora", Boal escrevia no exílio uma peça como Murro em ponta de faca (1976) e Guarnieri, trabalhos como Botequim (1973) e Um grito parado no ar (1973). É possível vislumbrar, no entanto, uma diferença significativa entre este último texto e a sensação de melancolia posta em Check-up por Paulo Pontes. Optando pela metáfora e pela reflexividade como estilo, Guarnieri coloca em cena uma companhia teatral, composta por um diretor e cinco atores, que encara profundas adversidades enquanto tenta montar uma peça da qual saberemos poucas informações. Como se comentasse criticamente a própria condição da dramaturgia no enfrentamento com os mecanismos de repressão, discutindo o fazer teatral naquele contexto histórico, o autor expõe problemas de ordem política e econômica responsáveis por intensificar o esvaziamento de uma tradição artística de combate ideológico. Mais inspirado por Pirandello do que por Brecht, afastando-se do derrotismo anunciado em Check-up, Guarnieri fez de Um grito parado no ar uma peça de resistência: mesmo diante de todas as imposições possíveis, o grupo encontra-se decidido a montar seu texto. No decorrer dos ensaios, nos quais a constante é o descontrole emocional, revelam-se nos laboratórios dos atores, de forma latente, a opressão vivida no Brasil ditatorial. Assim como essa geração buscara restituir aos palcos o nacional-popular, repensando o seu compromisso com a crítica marxista, Guarnieri esforçava-se em devolver ao artista/militante, mesmo que posto à margem e sob o risco da anulação, um lugar possível de atuação política.

Seria, entretanto, apenas com Rasga coração (1974), peça escrita por Vianinha às vésperas da morte, que a dramaturgia de viés marxista passaria, para além do elogio recorrente ao militante, a pensar uma espécie de novo programa para o engajamento político por meio das artes. Na versão impressa de seu texto, Vianinha ofereceria, como prefácio a Rasga coração, um quase poema intitulado "Somos profissionais". Ali, entre sugestões formais para o teatro praticado por sua geração, questão que discutirei um pouco à frente, encontra-se uma avaliação fundamental sobre o novo papel a ser assumido pela dramaturgia de tradição política. Ao anunciar que a missão dos artistas não se definia mais pela perspectiva teleológica anterior, a de ser "juízes de nosso tempo", o autor anulava a ortodoxia comunista de suas primeiras peças para sugerir a atualização do exercício dialético a partir de uma crítica não normativa, aberta à compreensão materialista menos esquemática de Brasil. Destituída das imposições partidárias, que nos anos 1960 por vezes implicavam projetar uma leitura idealista da situação nacional, os dramaturgos encontravam-se, mesmo que reféns da ditadura, livres para a tarefa "de investigadores, de descobridores" das estruturas que organizavam 
uma realidade social repleta de fissuras e de contradições. Despido das ilusões totalizantes, o dramaturgo deveria continuar atuando nas especificidades de seu tempo, contribuindo para o despertar crítico dos espectadores. Se a Revolução, como transformação total, mostrava-se inviável, a solução estava na política de menor alcance, fundamental para construir, nos subterrâneos do país, um contradiscurso ao projeto dos militares. Da negação do monumentalismo que a arte marxista criara para autorrepresentar o militante heroico, Rasga coração anunciava um novo homem político, anônimo, que embora não fosse homenageado com uma estátua em praça pública, tornava-se fundamental na luta ao lado do popular. Desvelar os sintomas da crise, mesmo que em uma dimensão pequena, cotidiana, tornava-se algo pungente: "para achar a água é preciso descer terra adentro/encharcar-se no lodo/mas há os que preferem olhar os céus/esperar pelas chuvas".

Em Rasga coração, peça na qual Vianinha exercitou ao máximo o seu conhecimento teatral, o protagonista é Manguari Pistolão, militante comunista, que tem uma trajetória marcada por enfrentamentos constantes com o mundo a sua volta. No passado, quando jovem, encontra-se em confronto com a incompreensão do pai, integralista que em tempos de Getulio Vargas não aceita as escolhas profissionais e ideológicas do filho; no presente, já um homem casado, mas que não abandonou a atuação ao lado do popular, entra em choque com o filho Luca, hippie desinteressado em política que rejeita, em nome do prazer, submeter-se à lógica do mundo burguês. Com um esqueleto dramático no qual o passado e o presente se sobrepõem, como se as situações vividas em uma temporalidade fossem o espelho da outra, Vianinha coloca no palco, no centro do difícil relacionamento entre os personagens, a crise geracional. Nos anos 1970, consciente da derrota sofrida pela esquerda, Manguari sente nas conversas com Luca desprezo da juventude pelo comunismo, pelas estruturas hieráticas da sociedade e pela família burguesa como núcleo de organização das relações humanas. Em tudo o que o protagonista acredita e vive, seu filho vê aprisionamento, infelicidades, decadência: ambos são incapazes de aceitar os valores do outro, de negociar uma aproximação entre as visões distintas de mundo. Embora Vianinha, com muita habilidade, apresente diálogos eloquentes em torno do ponto de vista dos dois personagens, é evidente a sua adesão ao velho militante, ainda mais após a cena na qual Luca renega totalmente a tradição de luta dos comunistas ao dizer que "a história política deste país é a história da calça arriada".

Esse argumento que procura anular, sem conhecimento histórico, a contribuição crítica do marxismo, ponto de impasse para os dramaturgos formados sob a influência do PCB, estimula o desenvolvimento, nas sequências finais de Rasga coração, de um olhar simpático em torno de Manguari Pistolão. Ao avaliar, na figura do protagonista, a sua própria geração, o autor lhe presta uma dupla homenagem, esboçando na ficção o novo programa de atuação política. Em primeiro lugar, ao colocar em cena o personagem jovem Camargo Moço, que tem como inspiração para o seu engajamento a tradição de militância da es- 
querda tradicional, Vianinha apontava que o afastamento do idealismo anterior não implicava negar a herança marxista, mas em descobri-la em novo formato. Condenar os erros estratégicos dos anos 1960 não significava apagar da memória o passado de luta, mas compreendê-lo como parte de um processo que, revisado, poderia continuar estimulando a consciência crítica, o materialismo histórico como ciência e a desconfiança pelo exercício dialético. Tratava-se de fixar na história do Brasil a contribuição da esquerda, gerando uma resposta ao esvaziamento ideológico organizado pela ditadura. Uma disputa pela construção da memória do país que, em contrapelo à história oficial criada pelos militares, procurava inscrever na ficção o legado comunista: mesmo diante do sentimento de derrota, em que muitos textos pareciam velar um defunto incômodo, a busca estava na manutenção do espírito crítico, na ressurreição da militância no tempo presente. Não à toa, reconhecer heranças do marxismo é um dos tópicos centrais em peças como Ponto de partida (1976), de Guarnieri, e Campeões do mundo (1979), de Dias Gomes. Mesmo no cinema, ao adaptar Eles não usam black-tie (1981) em parceria com Guarnieri, o cineasta comunista Leon Hirszman adicionaria esse debate em um dos novos diálogos do personagem Otávio. No velório de seu amigo e companheiro Bráulio, símbolo de luta de uma esquerda perseguida, ele diz ao filho: "Nunca que um companheiro maravilhoso como esse ia pensar que tinha tanta gente importante no enterro dele. É só o Bráulio mesmo. Viu, Chiquinho? Um dia o teu filho vai estudar o Bráulio na História do Brasil".

Ao se autorrepresentar na ficção, o dramaturgo buscava garantir a permanência de sua tradição de luta não apenas na escrita da história, mas também na crítica ao tempo presente. Em Rasga coração, o segundo momento em celebração à permanência do legado comunista acontece quando, no ápice dramático, discussão final entre Luca e Manguari Pistolão, este último define o lugar possível do engajamento marxista em tempos ditatoriais. Como no quase poema "Somos profissionais", que prefaciava a sua peça, Vianinha desloca, na voz de seu protagonista, a atuação política de um viés totalizante para outro cotidiano, de alcance menor, mas não menos fundamental. Como combatente posto no anonimato, à margem da celebração heroica, Manguari mantém e dissemina a postura crítica a partir do enfrentamento com o dia a dia. Todo militante, mesmo isolado e comprometido com sua vida pessoal, respira rebeldia. Contra o esmorecimento provocado nos anos 1970, é esse o recado dado por intermédio do protagonista de Rasga coração:

Eu sempre estive ao lado dos que têm sede de justiça, menino! Eu sou um revolucionário, entendeu? Só porque uso terno e gravata e ando no ônibus 415 não posso ser revolucionário? [...] Revolução sou eu! Revolução pra mim já foi uma coisa pirotécnica, agora é todo dia, lá no mundo, ardendo, usando as palavras, os gestos, os costumes, a esperança desse mundo.

Ao propor para si o exemplo de Manguari Pistolão, saindo do texto idealista anterior para outro que buscava, a partir de um popular redefinido, apresentar os sintomas de uma sociedade corrompida, essa "dramaturgia de avaliação" 
reencontrava, naquele momento, um lugar específico - e possível - de atuação para a militância de esquerda. Com sua peça, Vianinha definia um caminho, uma base política, que boa parte de seus colegas de geração adotaria no teatro da segunda metade da década de 1970.

O repensar dos eixos temáticos de criação do teatro político não poderia, no entanto, para a geração de Vianinha, deixar de vir acompanhado por uma outra reflexão em torno de qual forma dramatúrgica seria a mais adequada para inquietar os espectadores à leitura crítica, materialista, da sociedade e de suas fissuras. No geral, autores como Guarnieri, Paulo Pontes e João das Neves, além do próprio Vianinha, assumiram uma postura de negação diante do que o teatro brasileiro vinha articulando, na passagem dos anos 1960 para 1970, como proposta de vanguarda. Para eles, a tendência iniciada por José Celso Martinez Corrêa, com a montagem de O rei da vela, em 1967, havia gerado uma adesão das novas companhias teatrais a uma encenação virtuosista, "pirotécnica", a partir da qual técnicas performáticas e de anulação da "ação dramática" estariam operando o esvaziamento do realismo como tradição fundamental para colocar nos palcos o drama social. Valorizando o papel do diretor como construtor de uma mise-en-scène agressiva, na qual o deboche era um artifício recorrentemente empregado para incomodar o público em relação às próprias moralidades, essa vanguarda apostava na ritualização da cena, no incômodo desvelar das subjetividades amortecidas pelos valores burgueses e no afastamento da dramaturgia política de viés comunista, que em suas idealizações havia falhado ao projetar uma revolução irrealizável como práxis. Ao romper com a racionalização marxista, peças como Cordélia Brasil (1968), de Antônio Bivar, e Hoje é dia de rock (1971), de José Vicente, incomodavam a geração egressa do Teatro de Arena pelo que consideravam uma adesão inconsequente à cultura de massa e pelo desligamento desse teatro em relação ao compromisso com o popular. Assim, praticamente sintetizando a indisposição dos autores politizados em relação a essa tendência, Paulo Pontes e Chico Buarque eram taxativos, no prefácio a Gota d'água, ao apontar como

o desespero, o deboche, a super-valorização dos sentidos, etc. - que tomaram conta de nosso melhor teatro em anos recentes - a partir de determinado momento deixaram de ser substitutivos conscientes do realismo policiado e passaram a ser, no plano teatral, a expressão da incapacidade de nossa cultura de perceber e formular, em toda a sua complexidade, a sociedade brasileira atual. (Buarque; Pontes, 1977, xviii)

Nesse e em outros textos em que a esquerda analisou o teatro brasileiro na primeira metade dos anos 1970, como na apresentação da peça $O$ último carro ou no artigo "Efeitos e causas (ou causas e efeitos) da crise" (1972) (Vianna Filho, 1983, p.149-53), redigido por Vianinha, a constante está no pressuposto de que essa vanguarda, embora apresentasse soluções inquietantes do ponto de vista formal, apontava uma profunda crise criativa nas artes dramáticas por dissolver a perspectiva realista de engajamento. Obviamente, os dramaturgos marxistas não 
desejavam, diante da falência do projeto revolucionário, retomar os traços de idealismo que estimularam na sua ficção um texto esquemático, cujo falso pressuposto fora, por vezes, a criação de tramas superficiais que permitissem uma eficiência maior na politização do espectador. Mesmo que a tendência anterior ao didatismo fosse, em grande parte, desenvolvida em encenações de evidente complexidade estética, e basta lembrar da aproximação com a forma brechtiana nas montagens de Arena conta Zumbi e Arena conta Tiradentes, o mal-estar gerado com a derrota da esquerda no campo ideológico levou os autores a apostarem em uma dramaturgia na qual a alteridade permitiria uma leitura mais profunda das estruturas sociais e do desvelar de suas contradições. Em defesa de uma "sofisticação" do drama comprometido com a política, para eles irrealizável no teatro daquela vanguarda, estava em jogo o resgate de um engajamento que permitira, na ficção, a continuidade de uma abordagem crítica em torno do Brasil. Se a tradição iniciada pelo Teatro Oficina estruturava-se no irracionalismo como mediação de mundo, anulando uma narratividade em progressão dramática que se pautava pela crítica do social, o caminho seria, ao inverso, reconduzir a "palavra", a lógica racional, ao centro da criação teatral, apostando que esse movimento seria capaz de gerar uma densa reflexão sobre a sociedade. Contra a "fobia pela razão", identificada no prefácio de Gota d'água como tendência da vanguarda, a perspectiva estava em revalorizar a linguagem: como

instrumento do pensamento organizado, (esta) tem que ser enriquecida, desdobrada, aprofundada, alçada ao nível que lhe permita captar e revelar a complexidade de nossa situação atual. A palavra, portanto, tem que ser trazida de volta, tem que voltar a ser nossa aliada. (Buarque; Pontes, 1977, p.xix)

Havia, por parte da maioria dos autores oriundos do Teatro de Arena exceção a Boal, sempre fiel à épica brechtiana -, a aposta no regresso à forma dramática, na consolidação de uma dramaturgia em que a síntese entre o desenvolvimento psicológico e social dos personagens permitisse a identificação dos espectadores com o universo do popular em crise. Em um movimento oposto àquela vanguarda, a um teatro assumidamente fragmentário e agressivo, surgia a confiança em uma estrutura dramática tradicional, de progressão narrativa, que acreditavam poderia incentivar o público a uma imersão emocional na cena e a uma reflexão trazida à tona pelo realismo crítico. Para os dramaturgos de viés marxista, diante de um espectador fatigado com os dispositivos hostis da vanguarda, tratava-se de devolver ao teatro o prazer de assistir a uma peça em que os recursos do drama, bem construídos, incluiriam também uma reflexão sobre a situação brasileira nos anos 1970. No respeito às normas convencionais de playwright, textos como Gota d'água, Rasga coração, Ponto de partida e Campeões do mundo procuraram estabelecer o jogo emocional como pressuposto necessário para a conscientização política. Mesmo que isso implicasse a perigosa aproximação com uma forma tradicionalmente utilizada pelo teatro comercial, e empregada sistematicamente pela televisão, os autores articularam o uso da catarse em consonância com o discurso crítico, esperando com isso fazer da ficção 
politizada também um espaço de abrigo, de lazer, em meio às pressões da ditadura sobre a vida social. Vianinha, um dos maiores defensores dessa perspectiva, faria das apresentações de Rasga coração uma espécie de carta de intenções dos dramaturgos de esquerda. Além do quase poema "Somos profissionais", em que expõe a sua oposição ao teatro de agressão, ${ }^{3} \mathrm{em}$ um dos prólogos inéditos da peça escreve:

aqui é um lugar de repouso e contemplação. Não queremos a sua participação, nem como agredidos, nem como coro de vozes divididas [...] só nesse estado desavisado, descontraído, blandicioso, poderemos deixar alguns talantes em sua alma que sirvam para medir os tamanhos reais da vida. Esperamos que essa doce sensação de gratuidade à saída do teatro, amanhã nas ruas, as coisas corriqueiras ganhem outro significado para os senhores. (Vianna Filho, 1983, p.188-9)

Assim, levando aos palcos um contradiscurso essencial para marcar oposição ao governo militar, rearticulando o nacional-popular e a representação do militante como eixos para a leitura em torno das contradições brasileiras, a "dramaturgia de avaliação" apostava no vigor que a forma dramática poderia ter para operar sobre o público, carente de identificações emocionais, uma transformação crítica do olhar. Das inquietações dos dramaturgos politizados, surgia um teatro que, embora de curta duração, sem lugar para realizar-se nos palcos das décadas seguintes, acabou por revelar-se uma sobrevida da tradição ficcional marxista capaz, naquele momento, de oferecer um importante local de reflexão para uma sociedade anestesiada pelo autoritarismo ditatorial. Foi uma contribuição, fundamental, da geração formada pelo comunismo e que buscava resistir à própria crise de seu projeto revolucionário.

\section{Turma, doce turma (1974), de Vianinha: contribuição televisiva para o debate}

A partir de 1968, com o endurecimento do regime militar, a ampliação da censura às peças politizadas e a crise econômica do mercado teatral, dramaturgos comprometidos com o marxismo precisaram encontrar em outro meio de expressão uma oportunidade de segurança financeira e de desenvolvimento de seus trabalhos criativos. Estimulados por comunistas da velha guarda que atuavam na televisão há anos, caso de Dias Gomes e Bráulio Pedroso, nomes como Gianfrancesco Guarnieri, Paulo Pontes e Vianinha acabariam por trabalhar nas emissoras Tupi ou Globo, dispostas no início dos anos 1970 a afirmar-se culturalmente com a incorporação em seus quadros do que havia de mais significativo no teatro brasileiro. Na televisão, que se mostraria um "refúgio" repleto de contradições, esses autores conseguiram manter traços de engajamento em roteiros de crítica à classe média, transformados em programas como As pessoas na sala de jantar (1972), ${ }^{4}$ mas encontrariam uma indisposição crescente aos textos próximos da "dramaturgia de avaliação", nos quais a autorrepresentação do militante e a leitura politizada do popular eram os pontos de partida para a análise de Bra- 
sil. Nos poucos momentos em que buscaram manter o compromisso ideológico com o povo, os autores de tradição comunista tiveram que encarar não apenas a perseguição de órgãos governamentais às suas obras, mas também a própria autocensura das emissoras, mais interessadas em ficções com forte apelo de público nas quais o popular era tratado como cultura festiva ou a partir de crises individuais sem relação com o social. Um caso como o do programa Pivete (1972), roteirizado e dirigido por Guarnieri, mas impedido pela Tupi de ser veiculado, mostrava como estavam fechados, na televisão, os espaços para a realização de dramas como o do personagem favelado Nenê, cuja guinada ao banditismo era consequência da fome e da exploração na esfera do trabalho. Embora interessasse uma ficcionalidade originária de autores à esquerda, esta deveria ser contida em sua rebeldia, amoldando-se a padrões mais palatáveis de consumo cultural. O centro de desenvolvimento da "dramaturgia de avaliação" parecia ser mesmo o teatro, embora esse passasse por uma aguda crise econômica e de identidade.

Em meio a esse processo televisivo de "acomodação", em que a ficcionalidade em torno do popular perdia seu componente político-marxista para ser incorporada pela indústria cultural, no entanto uma rara exceção foi possível no ano de 1974. Às vésperas da morte, enquanto escrevia a peça Rasga coração, Vianinha aceitou o convite da Globo para redigir o piloto de uma nova série que a emissora pretendia lançar ainda naquele ano. Partindo da comédia de costumes com tonalidade crítica, que o dramaturgo exercitara na criação de $A$ grande família, o novo roteiro, intitulado Turma, doce turma, apresentava um grupos de amigos, todos pertencentes à classe popular, alguns trabalhadores autônomos e outros operários, que há quinze anos se reuniam nas noites de sábado para celebrar a vida e relaxar diante da luta do dia a dia pela sobrevivência. O texto começa com mais uma dessas reuniões, com os personagens se encontrando após o expediente, mas reserva uma surpresa, uma situação de inescapabilidade que lembra as narrativas de peças como Check-up e Um grito parado no ar: naquele dia, embora os amigos tentem encontrar em São Paulo um local para festejar, acabam por viver a frustração diante de uma metrópole tomada pela violência, pelo medo e pela burocratização. Embora insistam na busca por um lugar aprazível, acolhedor, esbarram nas transformações agressivas praticadas pela modernização urbana dos anos 1970, em que a privatização constante dos espaços públicos e a institucionalização da violência pelos mecanismos autoritários do poder esvaziaram a grande cidade como local de debates, de convivência e sociabilidade. Posto à margem, diante da impossibilidade da celebração, o popular é colocado por Vianinha no centro da dramaturgia como reflexão sobre o Brasil ditatorial.

A partir do realismo como estilo, em uma forma estética que partia do jogo emocional como princípio para a conscientização do espectador, Turma, doce turma permitia elaborar na televisão um diálogo com a "dramaturgia de avaliação", especialmente em relação ao resgate do nacional-popular como exercício dialético de crítica política. No jogo de enfrentamentos, entre as expec- 
tativas e frustrações dos personagens, o texto revelava fissuras e contradições existentes na metrópole. Em princípio, levando em conta a recorrente autocensura da Globo em relação ao viés marxista de abordagem do povo, o roteiro estaria possivelmente destinado ao engavetamento. No entanto, talvez pelas circunstâncias, a recente morte de Vianinha, autor que contribuíra bastante nas pesquisas de uma linguagem ficcional para a televisão, Daniel Filho resolveu supervisionar a transformação do piloto de Turma, doce turma em um episódio fechado dos Casos especiais, trabalhando em parceria com Paulo Affonso Grisolli, que ficou responsável pela direção do programa. O clima de homenagem, informação importante para entender o processo de realização do programa, também está na origem da mobilização de antigos companheiros de Vianinha, todos provenientes do teatro engajado dos anos 1950 e 1960, que decidiram se organizar para estar presentes no projeto. Interpretando o grupo de amigos, estariam atores como Gianfrancesco Guarnieri, Milton Gonçalves, Flávio Migliaccio, Nelson Xavier e David José, todos com passagens significativas pelo Teatro de Arena, além de uma participação especial de Lélia Abramo, conhecida por sua militância comunista. Mesmo que Turma, doce turma se concentrasse no drama do popular para pensar criticamente traços do Brasil, a união desse elenco, de rostos fortemente identificados com a tradição de peças politizadas, acabaria por incluir na obra televisiva, de modo latente, o eixo de representação do militante praticado pela "dramaturgia de avaliação". Em uma síntese com o povo à deriva, na impossibilidade de celebração, encontravam-se os próprios militantes de esquerda.

Turma, doce turma, o programa, começa com uma imagem, retomada de diversos modos a cada abertura de bloco, cuja força provém de anunciar um sintoma da metrópole em transformação: a captura de um breve fragmento noturno da cidade, em plano aberto, revela nas luzes em movimento o tráfego ininterrupto de automóveis, o engarrafamento como sinal de uma modernização atropelada a imprimir na vida urbana uma dinâmica de opressão e de esgotamento. Embora o problema já se encontre apresentado nessa imagem inicial, a primeira parte do roteiro de Vianinha, em que predomina um tom afável de comédia de costumes, introduz o núcleo dramático central e suas expectativas de felicidade a partir do encontro entre os amigos no sábado. A cada aparição de um dos componentes da turma, em que o violão de Edu Lobo retoma a batida dos afrossambas para marcar a musicalidade do popular, o espectador é apresentado a personagens urbanos que, entre jogos, provocações e brincadeiras, destacam o seu lugar social na cidade de São Paulo. Como se houvesse um diálogo livre com o realismo de inspiração lukácsiana, o programa introduz, em um cenário de aparência idílica, composto por um banquinho de praça e um poste de luz, os tipos de uma classe popular existente nos anos 1970: na síntese dos traços psicológicos e sociais dos personagens, Turma, doce turma apresenta, entre os amigos, Epaminondas (Milton Gonçalves), negro que trabalha em uma fábrica de creolina; um japonês (José Uehara) funcionário de quitanda; Osval- 
dinho (Guarnieri), descendente de italianos que faz propagandas de produtos médicos; um malandro (Nelson Xavier) com sua motocicleta; Peducci (Flávio Migliaccio), que concerta telefones; e um operário (David José). Nesse primeiro bloco do programa, as poucas marcas de tensão entre a cidade e os amigos - a desconfiança dirigida por um comerciante a Epaminondas ou as reclamações de um senhor contra o barulho da turma - são sutis e acabam por praticamente se anular diante da comicidade da cena, em especial o tumulto gerado na família do personagem de Guarnieri quando esse conta uma mentira para passar a madrugada com os amigos.

É somente a partir da segunda parte de Turma, doce turma que uma mudança de tom começa a se anunciar. Após descobrir que a informação de uma festa para aquele sábado era falsa, o grupo de amigos, instigado pela pergunta do personagem de Nelson Xavier, "afinal, qual o programa para hoje à noite?", resolve ir a um salão onde poderão conversar e jogar sinuca. A cena, ainda repleta de brincadeiras, transmite animação e promessa de divertimento, até que um corte, ao provocar uma elipse na narrativa, conduz a turma a um lugar lotado, onde precisarão aguardar um tempo na fila antes de iniciar o jogo. A inversão das expectativas, porém, só acontece realmente quando, após conseguir a mesa de bilhar, os amigos são surpreendidos por dois malandros armados com revólver na cintura e que tomam posse da mesa, praticamente os expulsando do bar. $\mathrm{O}$ assombro diante de um espaço que já fora acolhedor e agora se encontra tomado pelo banditismo imprime no programa um comentário crítico em torno de uma cidade - o Brasil, por extensão - na qual passa a predominar a tensão e o esgotamento, consequências de uma modernização oposta àquela esperada pelos marxistas. Se um dia, durante sua atuação no Centro Popular de Cultura, Vianinha apostara, em textos como "Teatro de rua" (1962-1963) (Vianna Filho, 1983, p.98-9), no espaço público como lócus ideal de engajamento e de promoção do debate político, os anos de desmonte ideológico da esquerda e de institucionalização da violência fizeram que repensasse a sua leitura. Há agora a amargura de observar uma urbanidade que se encontra em colapso, na qual as estruturas do autoritarismo geraram uma fissura a impossibilitar as sociabilidades, a impedir a realização do encontro com o popular. A frustração dos amigos diante dessa falência, revelada na sequência do bilhar, em especial na panorâmica a correr os rostos cabisbaixos dos personagens após o confronto com os malandros, é também o sentimento de uma esquerda que enfrenta a própria crise de seu projeto de mundo.

O restante da narrativa de Turma, doce turma prossegue nessa avaliação de um popular que, em síntese com o próprio militante, encontra-se posto à margem. Após a passagem pela sinuca, ainda ansiosos por definir "um programa" para aquela noite, os amigos resolvem ir a um local do qual guardam ótimas lembranças, uma praça chamada Formosinho, onde um clima de cidade interiorana, com música e casais passeando, poderia preencher as expectativas de felicidade. Entretanto, o desânimo é intensificado após descobrirem, na conversa 
com um sujeito amedrontado, que em nome do progresso o local está sendo demolido para a construção de um viaduto e de uma estação de metrô. Embora a sequência adicione mais um componente de deterioração urbana, agora nos descaminhos do poder político para permitir a mobilidade em massa na metrópole, a ação dramática em torno da praça em desaparecimento carrega um fator simbólico fundamental na "dramaturgia de avaliação" da esquerda, presente em peças como Rasga coração ou Ponto de partida: o desmoronar de um espaço público acolhedor em consequência de uma política agressiva de desenvolvimento econômico é metaforicamente o soterrar da própria memória social. Vivendo uma condição marginal dentro da cidade, para além da impossibilidade do encontro e da expressão cultural, a turma também passa pela supressão histórica do tecido urbano, por extensão o apagamento de sua própria memória como classe. Ao evocar na ficção um dos grandes dilemas de metrópoles como São Paulo e Rio de Janeiro, nas quais a especulação imobiliária operou - e continua a operar - a anulação dos lócus tradicionais de convivência, Vianinha articula a sua visão crítica de um país onde os poderes estabelecidos aniquilam a história em nome do futuro. O desfrutar do espaço urbano, cada vez mais privatizado, passava a se tornar um processo de seleção estabelecido pela condição econômica.

À deriva, com seu humor oscilando entre a tristeza diante dos acontecimentos e o alívio gerado por estarem entre companheiros, a turma acaba por retornar ao ponto inicial da trama, local composto por traços idílicos onde há anos se encontram. Como um possível refúgio diante das opressões da cidade, os amigos tentam, ali, estabelecer um ponto de resistência, um respiro para que a reunião entre eles não termine melancólica. Ao ouvir novamente, da voz cansada do personagem de Nelson Xavier, a pergunta "qual o programa para hoje à noite?", resolvem retomar antigas brincadeiras na tentativa de reencontrar a alegria que possuem. No entanto, mesmo se divertindo com um jogo em que narram partidas de futebol, encaram uma nova frustração com a chegada da polícia, chamada por um sujeito incomodado com o barulho, burocrata cujo espírito vive rodeado pela crença nos números. Presos por estarem naquela noite sem seus documentos de identidade, um ato de rebeldia que até o momento encaravam como brincadeira, são jogados em uma cela superlotada, passando o restante da madrugada na delegacia. O processo de esgotamento do popular, gerado em Turma, doce turma a partir do acúmulo das situações de autoritarismo na metrópole, termina com o mal-estar dos personagens que se despedem, exaustos, após serem liberados pela polícia na manhã do domingo. Embora ainda brinquem um com o outro, pois a amizade não deixa de ser um alívio às tensões do cotidiano, permanece no desfecho da trama um clima de desorientação, de desengano: Epaminondas, que no início da narrativa fora o primeiro a chegar ao ponto de encontro, anuncia o medo da solidão, seu cansaço em relação a São Paulo e a vontade de largar tudo para regressar à sua cidade de origem.

Turma, doce turma é um programa em cuja origem está a habilidade de Vianinha em fazer do cômico um estilo possível para o exercício da crítica na 
televisão. Na trajetória desse grupo de amigos à deriva, situações hilárias e momentos de decepção alternam-se para compor uma narrativa em cuja evolução dramática transparece a melancolia diante das transformações observadas na grande cidade. Curioso, porém, é notar que o autor, em seu compromisso político com o popular, nunca aderiu a uma perspectiva na qual a crise do projeto de esquerda significaria a sua dissolução total no panorama histórico vivido pelo Brasil dos anos 1970. A turma, embora sufocada, permanece um símbolo de resistência: ainda representa, conforme sugerido pelo letreiro que abre o programa, o "mistério" da solidariedade humana. Como um complemento a Rasga coração, peça na qual Vianinha define o possível lugar da militância em tempos ditatoriais, Turma, doce turma projeta, na amizade entre tipos do povo, um espaço simbólico de sobrevivência aos percalços da vida. Não à toa, há no roteiro televisivo uma espécie de positividade, resquício do ânimo comunista em esboçar na massa a tarefa de transformação social, que o autor tenta retirar dos escombros da metrópole em deterioração.

Na sequência da praça Formosinha, em solilóquio, o personagem operário retoma um viés de engajamento que mesmo abafado na História insiste em reaparecer, em não morrer:

Às vezes eu vejo esta cidade toda quebrada, toda estilhaçada. Sinto um desânimo. Mas aí eu chego na fábrica, vejo os colegas de trabalho, as máquinas [...]. Eu me sinto entusiasmado de morar aqui. Desafiar a natureza, permitir que milhões possam viver juntos ao mesmo tempo. Então, me parece que São Paulo é uma flor que vai desabrochar.

Esse discurso de traços românticos, anunciado na obra de demolição da praça, acaba, no entanto, por anular-se no primeiro momento em que é dito. Epaminondas, para quem a fala era dirigida, acaba no meio dela por ser tragado por um buraco, gerando o estranhamento de uma alocução política que parece impedida de chegar a seu destino. A carga simbólica da sequência realiza-se em torno de uma outra impossibilidade, para além das tensões existentes na metrópole: o popular, para quem se articula o discurso, é bruscamente retirado de cena no momento em que está prestes a escutar que o idealismo, força de toda a rebeldia, ainda permanece de alguma forma. Embora o espectador acompanhe toda a fala do operário, a quem pelo menos ela é inteiramente dita, a sensação deixada pela ficção é de uma resistência perdida no vazio. Entretanto, ao término da trama, quando Epaminondas já se despediu dos amigos e desce a ladeira em direção à sua casa, o mesmo discurso do operário, agora falado mais calmamente, ecoa pela cidade em seu amanhecer. No momento mais melancólico de Turma, doce turma, Vianinha rebate a decepção dos amigos permitindo o retorno de um tom idealista: apesar de tudo, em uma dramaturgia que revela os sintomas da crise, há a confiança na permanência de uma perspectiva de luta, de encontro político entre o popular e a militância. Como em Rasga coração, é o tributo que o autor presta, às vésperas da morte, à memória e à continuidade de sua geração como articuladora de um projeto ideológico de transformação social do Brasil. 
Notas

1 A escrita deste artigo só foi possível graças aos debates promovidos pela disciplina "Teatro e política no Brasil: do Teatro de Arena ao teatro de grupo contemporâneo", ministrada pelo professor João Roberto Faria na Faculdade de Filosofia, Letras e Ciências Humanas da USP.

2 Tomo de empréstimo o conceito de Raymond Williams conforme utilizado em Ridenti (2010).

3 Vianinha escreve, no quase poema "Somos profissionais": "não vamos agredir / agredir não é fácil, mas transfere responsabilidades / viemos aqui cumprir a nossa missão / a de artistas".

4 Inspirando-se na música Panis et circenses, de Gilberto Gil e Caetano Veloso, Guarnieri escreveu o roteiro As pessoas na sala de jantar para a Tupi. No texto, que foi transformado em programa, há uma denúncia à classe média a partir do enredo de uma família que se alivia com a morte da amante do pai, moça cujo sumiço é fundamental para manter a aparência social de tranquilidade.

\section{Referências}

ARRABAL, J.; LIMA, M. A. de. O nacional e o popular na cultura brasileira. Teatro. O seu demônio é beato. São Paulo: Brasiliense, 1982.

BETTI, M. S. Oduvaldo Vianna Filho. São Paulo: Edusp, 1997.

BOAL, A. Tentativa de análise do desenvolvimento do teatro brasileiro. Arte em Revista, São Paulo, n.6, p.8-11, out. 1981a.

4, 1981b.

O que pensa você do teatro brasileiro. Arte em Revista, São Paulo, n.2, p.40-

BUARQUE, C.; PONTES, P. Apresentação. In: Gota d’água. 5.ed. Rio de Janeiro: Civilização Brasileira, 1977. p.xi-xx.

COSTA, I. C. A hora do teatro épico no Brasil. Rio de Janeiro: Graal, 1996.

COUTINHO, C. N. No caminho de uma dramaturgia nacional-popular. Arte em Revista, São Paulo, n.6, p.60-1, out. 1981.

FARIA, J. R. O teatro na estante. São Paulo: Ateliê, 1998.

GOMES, D. O engajamento: uma prática de liberdade. Revista Civilização Brasileira, Teatro e Realidade Brasileira, Rio de Janeiro, caderno especial, n.2, p.7-17, jul. 1968.

GUARNIERI, G. O teatro como expressão da realidade nacional. Arte em Revista, São Paulo, n.6, p.6-7, out. 1981.

LEMOS, T, de. A guinada de José Celso. Entrevista. Revista Civilização Brasileira, Teatro e Realidade Brasileira, Rio de Janeiro, caderno especial, n.2, p.115-30, jul. 1968.

MACIEL, D. A. V. Ensaios do nacional-popular no teatro brasileiro moderno. João Pessoa: Editora Universitária UFPB, 2004.

MARTINS, C. E. Anteprojeto do manifesto do CPC. Arte em Revista, São Paulo, n.1, p.67-80, jan.-mar. 1979.

MORAES, D. de. Vianinha - cúmplice da paixão. Rio de Janeiro: Record, 2004. 
NEVES, J. das. Apresentação da peça O último carro. Arte em Revista, São Paulo, n.6, p.59, out. 1981 .

PEIXOTO, F. Teatro em pedaços (1959-1977). São Paulo: Hucitec, 1980.

Entrevista com Gianfrancesco Guarnieri. In: Teatro em movimento. São

Paulo: Secretaria de Estado da Cultura; Hucitec, 1985. p.44-60.

. (Org.) O melhor teatro do CPC da UNE. São Paulo: Global, 1989.

PRADO, D. de A. O teatro brasileiro moderno. São Paulo: Perspectiva, 2003.

RIDENTI, M. Brasilidade revolucionária, um século de cultura e politica. São Paulo: Ed. Unesp, 2010.

ROSENFELD, A. O teatro agressivo. In: Texto/Contexto. São Paulo: Perspectiva, 1996. p.45-57.

SCHWARZ, R. Cultura e política, 1964-1969. In: . Opai de família e outros estudos. Rio de Janeiro: Paz e Terra, 1978.

VIANNA FILHO, O. Vianinha - teatro, televisão, politica. Org. Fernando Peixoto. São Paulo: Brasiliense, 1983.

RESUMO: Nos anos 1970, diante da repressão militar e do colapso do projeto político da esquerda tradicional, autores teatrais como Gianfrancesco Guarnieri, Vianinha, Paulo Pontes e João das Neves realizaram uma revisão em seus escritos com a finalidade de retomar a tradição de uma dramaturgia engajada capaz de refletir sobre a crise da sociedade brasileira. Renegando o idealismo revolucionário de anos anteriores, buscaram um novo exercício dialético ficcional capaz de manter o compromisso ideológico na chave do nacional-popular e oferecer, pela emoção dramática, um caminho para a conscientização política dos espectadores.

PALAVRAS-CHAVE: Dramaturgia de avaliação, Brasil dos anos 1970, Nacional-popular, Teatro político, Marxismo nas artes.

ABSTRACT: In the 1970's, front of military repression and the collapse of the political project of the traditional left, playwrights like Gianfrancesco Guarnieri, Vianinha, Paulo Pontes e João das Neves conducted a review in their writings in order to retake the tradition of an engaged drama capable to think about the crisis of the Brazilian society. Denying the revolutionary idealism of earlier years, sought a new dialectical and fictional exercise able to maintain ideological commitment with national-popular and able to use the dramatic emotion as a way for the political awareness of spectators.

KEYWORDS: Dramaturgy of evaluation, Brazil of the 1970's, National-popular, Political theater, Arts and marxism.

Reinaldo Cardenuto é doutorando em Meios e Processos Audiovisuais na ECA-USP e professor de História do Cinema na FAAP. @ - reicar@uol.com.br

Recebido em 26.9.2011 e aceito em 22.12.2011. 